\title{
LUT
}

University

\section{HRM, Trust in Employer and Organizational Performance}

\author{
Vanhala Mika, Dietz Graham
}

This is a Final draft

version of a publication

published by John Wiley \& Sons, Ltd.

in Knowledge and Process Management

DOI: $10.1002 / \mathrm{kpm} .1491$

Copyright of the original publication: (c) 2015 John Wiley \& Sons, Ltd.

Please cite the publication as follows:

Vanhala, M., Dietz, G. (2015). HRM, Trust in Employer and Organizational Performance. Knowledge and Process Management, vol. 22, iss. 4, pp. 270-287. DOI: 10.1002/kpm.1491

This is the peer reviewed version of the article, which has been published in final form at https:// doi.org/10.1002/kpm.1491. This article may be used for non-commercial purposes in accordance with Wiley Terms and Conditions for Use of Self-Archived Versions.

This is a parallel published version of an original publication. This version can differ from the original published article. 


\section{HRM, TRUST IN EMPLOYER AND ORGANIZATIONAL PERFORMANCE}

\section{INTRODUCTION}

During a recent couple of decades researchers have been studied knowledge management and its' role in success of the organizations and how those can gain sustainable competitive advantage (see e.g. Drucker 2001, Holsapple and Joshi 2000). Within literature on knowledge management, trust has been often noted as a crucial factor for the success of knowledge management practices (e.g. Roberts 2000, Ford 2004). For example, trust's role in knowledge sharing has been widely studied (see e.g. Ozlati, 2015) and recently also the role of trust in knowledge protection has caught attention (Olander et al., 2015). In sum, trust within and between organizations both support and enable collaboration and knowledge sharing (cf. Politis, 2003).

Lately, the discussion about the intellectual capital has also pointed out the role of trust. Nowadays trust is seen, not only as part of the social capital, (see e.g. Demartini, 2015; Inkinen, 2015), but moreover as an independent dimension of intellectual capital i.e. trust capital (Kianto et al. 2014) which refers to trait of trust that adds value to internal and external relationships of the organization (e.g. Mayer et al., 1995). 
Also the role of trust as an enabler of organizational change has drawn the attention by the researchers (e.g. Saunders et al. 2003). For example, according to Morgan and Zeffane (2003) the trust within the organization is essential feature of change, and especially on changes of the workplace structure. The nature and built-in risk related to organizational change makes trust as central phenomenon in order to further understand the change process, e.g. by how employees perceive the change (Neves and Caetano, 2006).

On the other hand, according to recent study by Inkinen and colleagues (2015), for example, human resource management practices -hereafter HRM- play a significant role in knowledge management. Typically HRM practices include practices such as recruiting, compensation, performance appraisals, and training and development. These type of practices are substantially related on how to manage knowledge of the organization, and consequently Inkinen et al. (2015) argue that these can be, in fact, called and described as knowledge management focused HRM practices. The HRM practices selected by an organization are understood to work by shaping employees' work-related attitudes and behaviours in ways that are strategically valuable to the organization (Guest, 1997; Paauwe, 2009; Wood \& Wall, 2005; Wright \& Boswell, 2002). Their work-related attitudes are hypothesized to influence employees' job performance through, for example, exerting more or less effort, and (in)attention to 
quality, productivity and innovation. Cumulatively, superior performance from individual employees impacts positively on unit-level and, arguably, organization-level metrics. This sequence is known as the 'black box' model of HRM (Pauuwe, 2009: 134), the 'black box' being the logical "linking mechanism" (Wood, 1999: 408) between the cause (HRM) and its effects ('performance', however measured). In order for HRM to make sense, the content of the 'black box' - the decisive employee attitudes that realize HRM's effect on performance - must be understood. Yet what remains unclear, still, is which of the several candidates for the mediating variable carries the greatest explanatory power (Delery, 1998: 289). This would be useful knowledge for employers, to help them orientate their HR policies toward the attitudes that best deliver valuable employee performance.

Surprisingly few studies have tried to 'unlock' the box. In Boselie, Dietz and Boon's (2005: 11) review of 104 studies published between 1995 and 2004, just 20 studies featured "identifiable mediating effects" in the findings. Studies have confirmed mediation models using commitment, work climate, OCB and morale - by Ahmad and Schroeder (2003), Gelade and Ivery (2003), Snape and Redman (2010), and van den Berg et al (1999) respectively. However, some studies have found these, and other candidates, wanting. Kuvaas (2008), for example, found no support for a mediating role of the employee-organization relationship from perceived organizational support, 
affective commitment, procedural justice and interactional justice. The black box riddle remains unsolved.

In this study, we explore the merits of another mediation candidate: 'trust in the employer organization'. Our reasons are three-fold. First, trust suffuses almost every HR policy (Robinson \& Rousseau, 1994; Whitener, 1997; Searle \& Skinner, 2011; Zeffane \& Connell, 2003). Appraisal policies, pay schemes, and career progression, to name but three, all rely upon trust in order to be effective. Trust's pertinence is not in question. Second, we argue that HRM determines to a significant extent how much employees trust their employer, and how much the organization trusts its employees (Whitener, 1997; 2001), by setting mutual expectations and constraining and incentivizing employees' behaviours (including managers). Third, we further argue that, of all the possible relationships that employees have at work (with their immediate line manager, their colleagues, their senior leaders: see Redman \& Snape, 2005), the trust that employees have in their employer as an organization is, theoretically speaking, the most significant for HRM interventions to attend to, and target.

Consequently, our study theorizes, using social exchange theory (SET), that individual employees' trust in their employer fully mediates the effect of their employer's HR policies and practices on performance at multiple levels of analysis. We test this model 
inside two different firms based in Finland. The paper proceeds as follows. The next section defines our central variable, trust, and presents our central theorizing, based on social exchange theory. We also review the literature on trust and HRM, leading to our hypotheses. We then present the method and findings from the two studies, before drawing conclusions as to how the findings contribute to the literatures on trust and HRM, and offering practical recommendations in the final section.

\section{How HRM influences employee performance through trust.}

Trust is most commonly defined as "a psychological state comprising the intention to accept vulnerability based upon positive expectations of the intentions or behavior of another" (Rousseau et al., 1998: 395). These expectations are based upon a set of beliefs about the other party's trustworthiness. In Mayer, Davis and Schoorman's (1995) model, these comprise an evaluation of the other party's ability (i.e. technical and interpersonal competence), benevolence (i.e. motives and intentions), and integrity (i.e. adherence to acceptable principles, including honesty and fair treatment). What follows the "intention to accept vulnerability" is a risk-taking act with respect to the trusted party, such as relying on them to do something on our behalf (with a concomitant reduction in our monitoring of them), or the disclosure of sensitive information (Dietz \& den Hartog, 2005; Gillespie, 2003). 
One commonly advocated theoretical rationale for the link between employees' positive work attitudes and their perceptions of their employer's trustworthiness comes from social exchange theory (see Coyle-Shapiro \& Conway, 2004; Cropanzano \& Mitchell, 2005). SET proposes that an exchange relationship develops between two parties when one provides a contribution to the other, creating an obligation upon the recipient to provide something beneficial to the donor in return (Blau, 1964). One of SET's basic tenets is that a sequence of positive exchanges will, over time, evolve into loyal and mutual commitments characterized by trust (Whitener et al., 1998).

In SET, rules and norms of exchange are understood to set 'guidelines' for the conduct and outcomes of these exchange processes (Cropanzano \& Mitchell, 2005). Thus, an organization's HRM practices can be seen as setting many of the rules of the employment relationship, throughout the employees' cycle of engagement with their employer - from recruitment through career progression and development and reward to exit. The signals sent by HR policies shape employees' expectations and obligations toward their employer, and vice versa, and the signals initiate a social exchange between employer and employee. Employees interpret the HR practices at their workplace (especially the intentions behind them and the benefits to be accrued from them) and, on the basis of these beliefs, decide to take the risk to engage in extra effort 
on behalf of their employer (which might go unrewarded), and to continue to work for their employer (despite alternatives).

If the employer demonstrates through its HRM policies and practices benevolence and support for its employees - particularly if this is seen to be beyond the normal bounds of employment contracts - as well as general competence, employees will be expected to reciprocate with proactive effort and greater commitment and loyalty in response. This, in turn, should induce effective work performance, in line with standard 'black box' models of HRM. Alternatively, employees may feel that their employer's HR practices do little to inspire confidence, or the promises and obligations perceived to be implied in the HR policies are not realized, or are broken in their implementation. If the signals are negative (hostile; unjust), employees' valuable work behaviours and performance will be diminished.

In sum, the bundle of the various policies either inspires employees' trust or provokes mistrust, or ambivalence (Lewicki et al., 1998). Thus, HRM may be designed to create a norm or "exchange paradigm" (cf. Whitener, 1997: 396) of mutually beneficial reciprocity (Aryee et al, 2002; Farndale et al., 2011), and this will, if successfully realised, result in employees' trust in their employer organization (Tsui et al., 1997; Zhang et al., 2008). Such theorizing points to a classic mediation model, wherein trust is 
the facilitating mechanism of the exchange of two valuable inputs and outputs: HRM from the employer, and high levels of performance from the employee.

Importantly, for our theorizing, HRM works by sending signals to employees about their employer's 'take' on the employment relationship, above all. In all but the most heavily unionised work settings, HRM is typically an organization-level construct, determined and designed by the employer, on behalf of the employer. In other words, HR practices are seen as emblematic of the employing organization as a whole, rather than a discrete set of people such as senior managers or the HR function itself, or any individual such as one's line manager. While HRM has been found to impact on these relationships, HR practices represent the organization's values and interests, and not necessarily those of particular individuals or groups. Hence, to assess HRM's impact on employees' trust, it is important that the measure of trust reflects respondents' views of the organization as an entity.

\section{HRM and trust - previous research.}

Several HRM practices have been found to predict levels of workplace trust. For example, Mayer and Davis' (1999) quasi-experiment into the impact of changes to an appraisal system found that the experience of a revised appraisal policy did improve employees' trust in senior management (1999: 133). Pearce et al. (2000) found that trust 
in co-workers increased in organizations in which general and transparent rules were applied uniformly to all employees. Tzafrir et al. (2004) found that employee development, as well as organizational communication, were directly associated with trust in managers. McCauley and Kuhnert (1992) also found that the effectiveness of a wide range of HRM practices (i.e. professional development opportunities, job security, the fairness of the performance-appraisal system) correlated with the employees' trust in their employer. Finally, trust in senior managers has been found to partially mediate the relationship between employee voice and organizational commitment (Farndale et al, 2011) - see also Whitener (2001), Six and Sorge (2006), and Searle et al. (2011).

Trust's impact on strategically valuable employee attitudes is also firmly established, including higher job satisfaction, organizational commitment, and a more agreeable psychological contract (see Searle \& Skinner, 2011). Trust has also been shown to enhance employees' work behaviours, including discretionary effort on behalf of a wide range of stakeholders (OCB), teamworking and knowledge sharing (for reviews, see Colquitt et al., 2007; Dirks \& Ferrin, 2001).

Trust's impact on actual performance is rather mixed (Dirks \& Ferrin, 2001), but several studies have found direct predictive effects for trusting relationships on team performance (De Jong \& Elfring, 2010), customer satisfaction (Simons, 2002), and sales 
and profit levels (Davis et al., 2000). The trust relationships studied in this regard include colleagues' trust in each other (De Jong \& Elfring, 2010), employees' trust in their leader (Davis et al., 2000; Simons, 2002) and - reversing the relationship supervisers' trust in their employees (Salomon \& Robinson, 2008).

However, surprisingly few studies have explored the role of trust in explaining HRM's impact on performance. In a key early study Tsui and colleagues (1997; Tsui \& Wu, 2005) compared four models of 'employee-organization relationship', differentiated by the inducements on offer from the employer and the employee obligations these sought to invoke. The authors included trust in co-workers as one of the attitudinal outcomes, and found that the 'mutual investment' approach (an open-ended, long-term social and economic exchange arrangement) delivered the highest levels of trust and the best performance figures, although the strictly transactional 'quasi-spot contract' model (minimal social engagement but high rewards attached to demanding performance targets) also did well for performance. In his studies involving UK local government workers, Gould-Williams (2003; 2007) found support for the hypothesis that HR practices can be a powerful predictor of two forms of trust (in the employer's systems and in interpersonal trust in the workplace), and that both types of trust had a beneficial effect on organizational performance. Positive employer-employee exchanges led to enhanced worker attitudes and behaviours, but negative exchanges can emerge from 
hostile managerial behaviours and indifference. A number of recent studies have explored trust's role as a moderator in this relationship (Innocenti et al., 2010; Alfes, Shantz \& Truss, 2012), but our interest here is in a mediation model.

There remains, therefore, a gap in the literature on trust's role in the HRM-performance relationship, notably in terms of mediation models. We now explain why the focal relationship for research into this link should be employees' trust in their employer as an organization.

\section{Trust in employer organization.}

It is recognized that trust operates at multiple levels inside organizations (Rousseau et al., 1998), and people at work are required to engage with many different focal parties (Settoon et al, 1996; Whitener, 1997; Redman et al, 2011). In terms of trust relations, these include their immediate boss (Davis et al., 2000; Salomon \& Robinson, 2008), their colleagues (De Jong \& Elfring, 2010) and their senior management team (Mayer \& Davis, 1999). This perspective, viewing trust as an interpersonal phenomenon, has tended to dominate the research on trust. But employees must also place their trust, to an extent, in the organized collective entity that is their employer (Gillespie \& Dietz, 2009; Maguire and Phillips, 2008; McCauley \& Kuhnert, 1992; Robinson, 1996; Searle

et al., 2011; Vanhala et al., 2011). Importantly, trusting a person and trusting an 
organization are two different processes (Blomqvist, 1997; Searle et al., 2011), requiring the interpretation not only of senior leaders' strategies and decisions, but also cultural norms and values, and - most pertinent for the purposes of this study - the organization's policies and practices for co-ordinating work, including its HRM. Importantly, these cultural, structural and procedural features should be seen as enduring beyond the tenure of the transient profile of the senior leadership team (Whitley, 1987).

The importance of trust in functional structures and institutions has been known for some time (Lane \& Bachmann, 1998), but the nature of contemporary work, arguably, renders employees' trust in their employer, as an entity, as more important than other trusting relationships at work, such as with bosses and colleagues. Not only has the operational environment facing many companies become more complex (from greater geographic dispersal, and heightened market volatility and competition) and hence subject to greater degrees of flux, but opportunities for face-to-face communication have become scarcer (because work is increasingly carried out in temporary and even virtual teams). Additionally, pressures of work can mean that managers' role as a technical expert (ensuring that performance targets are met) assumes primacy, at the expense of their role as supervisors to individual employees (Alvesson, 2004). Finally, not only can direct interpersonal relations be transient in that turnover among managers 
and colleagues can render personal ties vulnerable to demise; they can also be prone to individual whim, as every supervisor and manager varies in their leadership style and treatment of colleagues (see e.g. Kuvaas, 2008). Under such conditions, interpersonal trust at work may therefore be rather 'thin' and vulnerable (Adler, 2001; Zeffane and Connell, 2003), and too weak for comfort.

If, by contrast, employees believe that their employer organization is committed to operate competently (i.e. ability), demonstrate concern for staff well-being (i.e. benevolence) and treats stakeholders honestly and fairly (i.e. integrity), and has policies and practices in place to uphold this commitment (i.e. HRM), this can prove a more robust and more enduring relationship. This form of trust in the organization can materialize from employees' observation of, and participation in, the 'interactions and event cycles' that are set and sanctioned by the employer (Gillespie \& Dietz, 2009). These are created and sustained by the organization's senior leadership as highly visible role models, but also by the organization's systems and policies, structures, decisionmaking processes, and cultural values, as well as indirectly via external governance (for more detail on the construction of organizational trust, see Gillespie and Dietz, 2009; Tan \& Tan, 2000). Indeed, McCauley and Kuhnert (1992) have argued that employees derive evidence for trust in their employer less from interpersonal dealings with individuals, and more from the roles, rules, routines and structured relations established 
and sustained within the organization: in other words, forms of impersonal trust. Employees monitor and evaluate the work environment of their employer and, based on that they observe, decide whether to trust their employer or not. Trust in employer is determined primarily by the fairness and efficiency of its structures and systems, including its HRM practices. This makes sense, as these are likely to be more stable than interpersonal relationships for inertial reasons (i.e. the cost and commitment involved in setting the systems up, and changing them).

Relatively few trust studies have made use of measures specifically tapping employees' trust in their employer organization. Robinson (1996) found that graduates' trust in their employer was associated with lower levels of psychological contract breach. Aryee et al (2002) found that trust in organization is positively associated with employees' organizational commitment. Tan and Tan (2000) found a negative association with intention to quit. In a Chinese study, Zhang et al (2008) found that different 'employeeorganisation relationship' approaches and supervisory support have direct and synergistic effects on middle managers' trust in their employer. Searle and colleagues (2011) explored interaction effects among HRM, justice and trust in employer in a large-scale European study. We are aware of only one study that has gone on to make the link between HRM, trust and measures of performance (Tsui et al., 1997). They 
indeed found that HRM policies can have a decisive impact on performance, although they measured trust in co-workers.

\section{Hypotheses}

We theorize a standard mediation model for HRM, employees' trust in their employer and performance. The statistical tests for mediation (cf. Baron \& Kenny, 1986) require that the independent variable [i.e. HRM] should predict the dependent outcome [i.e. performance metrics] and the mediator [i.e. 'trust in organization'], but that the mediator should predict the dependent variable to such an extent that its effect accounts for much of the impact of the independent variable [HRM]. Thus, we hypothesize the following:

Hypothesis 1a-c: Employees' perceptions of HRM will be positively associated with a) individual-level performance, b) unit-level performance and c) organization-level performance.

Hypothesis 2: Employees' perceptions of HRM will be positively associated with employees' trust in their organization. 
Hypothesis 3a-c: Employees' 'trust in organization' will positively mediate the relationship between perceived HRM and: a) individual-level performance, b) unitlevel performance and c) organization-level performance.

\section{Measures}

All scales except organization-level performance were based on a five-point Likert scale $(1=$ strongly disagree, $5=$ strongly agree $)$. Organization-level performance was measured with a scale anchored by " 1 = very poor, 5 = very good". Some items were modified, in discussion with company representatives, to make the wording more relevant for each company context. All the measures and the reliability results for both studies are in Appendices 1 and 2.

Independent variable: 'Perceived HRM'. While there is still little agreement in the theorizing on HRM as to what an operationalization of HR practices should contain (see Boselie et al., 2005), we used the scale developed by Delery and Doty (1996), which comprises eight items covering the core policy domains of most HRM conceptualizations: learning and development, communication, performance evaluation and rewards, career opportunities, participation and job design. Respondents were asked to indicate the extent they consider each practice occurs in their organization. Thus, it is 
a perceptual measure of HRM, from the employees' experience (Wright \& Nishii, 2004).

Dependent variables. Performance is considered as the individual employee's subjective perceptions of performance at the individual, unit and organization levels. This is for two reasons. Firstly, the two companies were reluctant to share objective performance data and, second, we wanted to ensure comparability between different kinds of organizational units and organizations. While perceptual data may introduce limitations through increased measurement error and the potential mono-method bias, research has found that measures of perceived performance do tend to correlate positively with objective measures (see e.g. Delaney and Huselid, 1996; Robinson and Pearce, 1988). In addition, the validity of the subjective perceptions was ensured with the company representatives.

Individual performance was measured by three items. Two came from Robinson (1996). One item ("I am satisfied with my work performance compared to employees who do the same kind of job") was created by the researchers, and added to make the scale more reliable. Unit-level performance was measured by four items from Dvir and Shenhar (1992). Organization-level performance was assessed by three items from Delaney and Huselid (1996). The suitability of our performance measures, especially organization- 
level measures, was ensured with the company representatives. For example, both companies have extensive internal communication practices, to help respondents make the comparison with other firms.

Mediating variable. Organizational trust was measured with the seven-item scale developed, tested and affirmed by Vanhala et al. (2011). The scale is especially designed to assess employees' trust in their employer as an organization. It is derived from a rigorous theoretical review of the trust literature, as well as specific insights gained from an inductive investigation into employer and employee perceptions on the nature of trust in their organizations, involving focus groups inside 13 organizations. The items (see Appendix 1) cover the three essential attributes of trustworthiness (cf. Mayer et al., 1995), including the resilience, sustainability and competitiveness of the organization (i.e. its operational ability), positive staff expectations about their own future (i.e. organizational benevolence), and the organization's, and senior management team's, commitment to ethical conduct (i.e. integrity). Confirmatory Factor Analysis on data from 166 respondents from different organizations in Finland validated the scale. Item reliability was evaluated in terms of the path coefficients and squared correlations. Cronbach's alpha and construct reliability were used to assess the reliability of each latent component. In addition, a measure of average variance extracted was used. Construct validity was evaluated by means of convergent and discriminant analysis. 
Discriminant validity tests provided evidence of a conceptual difference between trust in employer organization trust and interpersonal trust. In terms of nomological validity, there was theoretical support for a relationship between trust in employer and its outcomes (i.e. in the individual employees' job satisfaction and commitment to the employer organization). Finally, cross-validation showed that the scale was generalizable, as it was tested on two samples of respondents, blue-collar and whitecollar (see Vanhala et al, 2011).

Control variables. We controlled for gender, age, education, occupational status (manager/non-manager), organizational unit and job tenure. Only job tenure had any effect: a statistically significant relationship with unit-level performance.

In order to evaluate the generalizability of our findings to different organizational and job contexts, we tested our hypotheses in two different settings.

\section{STUDY 1: FORESTRY COMPANY}

\section{Data collection and sampling}

Study 1 is based on a sample of blue-collar workers of a large forestry company in Finland. The data was collected in August-September 2008. In total, 700 questionnaires with a covering letter were distributed by the company representatives randomly among 
the firm's 1400 employees. We received 411 useable responses from eight units within two of the firm's mills (a 58.7\% response rate). Examples of a unit would be paper or pulp production teams, and maintenance service. As can be seen from Table 1, most respondents were male, with long tenure at the firm, and most had not attended tertiary education. Based on discussions with the company representatives as well as company annual reports, the demographics of our sample represent the population of the whole workforce.

\section{INSERT TABLE 1 ABOUT HERE}

\section{Analysis}

The first step was to validate the measurement model including HRM practices, trust in organization and performance by means of confirmatory factor analysis (CFA). Second, we used structural equation modelling (SEM) to test each hypothesis. The 411 cases were processed through LISREL 8.50, and PRELIS 2.50 was used to compute the covariance matrix. We used the maximum likelihood estimation method.

\section{Assessment of bias}

Given the data collection methods used, assessment of non-response bias was not possible in Study 1. The data relied on self-report measures, and therefore common 
method variance might have biased the findings. We used Harman's one-factor test (Podsakoff et al., 2003) in order to assess the risk of such bias. We conducted a principal component analysis that incorporated all the items from all of the constructs. The solution was investigated in order to determine the number of factors that are needed to account the variance of all of the items. The largest factor accounted for $30.6 \%$ of the variance, which suggests that common method variance bias was not a concern.

\section{Measurement model, reliability and correlations}

The CFA found that the loadings of all the items were high and statistically significant (Appendix 1), suggesting that they were all related to their specified constructs, verifying the posited relationships among the indicators and constructs. Cronbach alphas all exceeded the usual acceptance level of 0.70 , with the exception of organization-level performance $(\mathrm{CR}=0.61$; alpha $=0.59)$. We considered dropping the organization-level results due to the low alpha. However, as it nearly reached the lowest acceptable level (0.60: Hair et al., 2006), we report that set of results but they should be taken as suggestive.

We evaluated discriminant validity with the method recommended by Anderson and Gerbing (1988), comparing two models for each possible pairs of constructs. In the first 
model we let constructs correlate freely and in the second model the correlations were fixed as equal to one. All chi-square difference tests were significant, which indicates that all pairs of constructs correlated at less than one. Thus, there is evidence of discriminant validity.

Table 2 presents the correlation matrix, mean scores, standard deviations and alphas for all the main variables. There are statistically significant positive correlations between them all.

\section{INSERT TABLE 2 ABOUT HERE}

Structural equation modelling (SEM) was used to test our hypotheses. The results of the chi-square tests were not significant. However, this test has been found to be sensitive to sample size, and other tests can be used to assess the goodness of fit (Hair et al., 2006). It can be seen from the indices presented in Tables 3-5 that the models produced an adequate fit. According to Hair et al. (2006), RMSEA should be below 0.06 and GFI, CFI, NNFI and IFI should exceed 0.90. In all of our models these limits are met (see Appendix 1). 
Path models reflecting the posited relationship between HRM, trust and performance were estimated in order to test the hypotheses. The results of the path analysis are presented in Tables 3-5. We applied the method presented by Hair et al. (2006) to test mediation with SEM. First we tested as our base model full mediation (i.e. that HRM predicts trust in organization and trust in organization predicts performance). Then we tested whether HRM predicts performance (i.e. the direct effect). Finally we tested the partial mediation model (whether the relationship between HRM and performance remained significant once trust was included in the model). If the relationship between HRM and performance remains significant, following the introduction of trust, then partial mediation is supported.

\section{Individual-level performance.}

Table 3 reports the path coefficients and fit indices. The base model shows that the direct path from HRM to the mediator, and from the mediator to individual performance, are significant and in the directions hypothesized. The indices show a good fit for the base model $($ RMSEA $=0.047$; GFI, CFI, NNFI and IFI between 0.926 and 0.937 ). The direct-effect model exhibits a significant association between HRM and individual performance. There is also a good fit (RMSEA $=0.048$; GFI, CFI, NNFI and IFI between 0.924 and 0.935$)$. 
The partial mediation model shows that the paths from HRM practices to trust in organization, and from the mediator to individual performance, are significant. The model statistics also reveal good fit indices for this partial mediation model. The RMSEA for the path from HRM practices to individual performance was 0.048 and GFI, CFI, NNFI and IFI all fell between 0.926 and 0.936 . However, the path from HRM to individual performance is not significant in the partial mediation model after trust is included. Taken together, this analysis supports our hypotheses 1a, 2 and 3a: trust in organization is a full mediator between HRM and individual performance.

\section{INSERT TABLE 3 ABOUT HERE}

\section{Unit-level performance.}

Table 4 shows the path coefficients and fit indices for this relationship. In the base model, the direct path from HRM to trust, and from the mediator to unit-level performance, are both significant, and in the directions hypothesized. The indices show a good fit for the base model (RMSEA $=0.043$; GFI, CFI, NNFI and IFI between 0.933 and 0.945). The direct-effect model shows a significant association between HRM and unit-level performance with a good fit as well (RMSEA $=0.050$; GFI, CFI, NNFI and IFI between 0.917 and 0.928$)$. 
The model statistics also reveal good fit indices for the partial mediation model $($ RMSEA $=0.043$; GFI, CFI, NNFI and IFI between 0.934 and 0.945). The paths from HRM practices to trust, and from the mediator to unit-level performance, are both significant. However, as with individual performance, the direct path from HRM to unit-level performance is not significant (i.e. partial mediation is not supported). In sum, this analysis supports Hypothesis 1b, 2 and $3 b$ : trust in organization fully mediates the relationship between HRM and unit-level performance.

\section{INSERT TABLE 4 ABOUT HERE}

\section{Organization-level performance.}

Table 5 reports the path coefficients and fit indices for this relationship. The base model paths (from HRM to the mediator and from the mediator to performance) are significant and in the directions hypothesized. Moreover, the indices show a good fit for the base model (RMSEA $=0.046$; GFI, CFI, NNFI and IFI between 0.929 and 0.939). The direct-effect model also exhibits a significant association between HRM and organization-level performance, with a good fit (RMSEA = 0.055; GFI, CFI, NNFI and IFI between 0.901 and 0.922). 
The model statistics also reveal good fit indices for the partial mediation model $($ RMSEA $=0.047$; GFI, CFI, NNFI and IFI between 0.929 and 0.940). This model shows that the paths from HRM practices to trust, and from this mediator to organization-level performance are significant. Again, however, the path from HRM practices to performance is not significant. Taken together, this analysis supports hypotheses $1 \mathrm{c}, 2$ and $3 \mathrm{c}$.

\section{INSERT TABLE 5 ABOUT HERE}

\section{STUDY 2: 'ICT COMPANY'}

\section{Data collection and sampling}

Study 2 is based on a sample of white-collar workers of a large ICT company in Finland. The data was collected in May-June 2008 from 17 units within three R\&D centres. Examples of a unit in this study would be software engineering and hardware planning. A covering letter including a personal link to the questionnaire was sent to 1,384 potential respondents via email. A total of 304 completed questionnaires were received representing a $22 \%$ response rate. As can be seen from Table 1 , the majority were again men, but this sample was notably younger and better educated than the forestry workers, and had had much shorter careers with their current employer. Again, 
based on both discussions with company representatives and the company's annual report, our sample is representative of the workforce s a whole.

\section{Analysis}

For the basic statistics on the validity of the measures for this study see Appendix 2. We applied exactly the same analysis to Study 1 as we did for Study 2.

\section{Assessment of bias}

Again, we used Harman's one-factor test to assess the bias of common method variance. We conducted a principal component analysis and the largest factor accounted for 29.4 per cent of the variance, which suggests that common method variance bias was not a concern. Additionally, an analysis of variance (ANOVA) was carried out in order to confirm the absence of non-response bias. It was assumed that those who were among the last to respond most closely resembled non-respondents (Armstrong \& Overton, 1977). The early and late respondents were compared on all constructs, and no significant differences between them were found. Thus, non-response bias was not a problem in this study.

\section{Measurement model, reliability and correlations}


In the CFA to validate our measurement models, loadings for all the items were high and statistically significant (see Appendix 2); they were all related to their specified constructs, verifying the posited relationships among the indicators and constructs. In terms of construct reliability and the Cronbach's alpha, all constructs exceeded an acceptable level of 0.70 , with the exception of organization-level performance $(C R=0.67$ and alpha 0.65$)$, which is just short of the usually accepted limit but above the lowest limit (0.60 - cf. Hair et al., 2006). So, again, we decided to run this analysis for this study. For the measurement models' fit indices, see Appendix 2. Again, all fit indices are within the acceptable limits: RMSEA below 0.06 and GFI, NNFI, CFI and IFI above 0.90 (Hair et al., 2006). As with study 1, we evaluated discriminant validity. All chi-square difference tests were significant (i.e. all pairs of constructs correlated at less than one), and so there is evidence of discriminant validity.

Table 6 presents the correlation matrix, mean scores, standard deviations and Cronbach's alphas for all the main variables. As in study 1 , there are statistically significant positive correlations between them all.

INSERT TABLE 6 ABOUT HERE

\section{Analysis}


SEM was used to test our hypotheses. Again the fit indices for the models were adequate (see Tables 7-9). Most of these limits are met in our models. In all levels of performance NNFI falls somewhat short (0.89). However, as a whole our models present adequate fit. The results of the path models reflecting the posited relationship between HRM, trust in employer organization and the different levels of performance are also presented in Tables 7-9.

\section{Individual-level performance}

For the path coefficients and fit indices, see Table 7. The base model shows that the direct paths from HRM to trust in organization, and from trust to individual-level performance, are both significant, and in the directions hypothesized. The indices show a good fit for the base model (RMSEA = 0.053; GFI, CFI, NNFI and IFI between 0.898 and 0.913). The direct-effect model exhibits a significant association between HRM and individual-level performance. There is also a good fit (RMSEA $=0.055$; GFI, CFI, NNFI and IFI between 0.892 and 0.910 ).

The partial mediation model $(\mathrm{RMSEA}=0.053$; GFI, CFI, NNFI and IFI between 0.898 and 0.913 ) shows that the paths from HRM practices to trust in organization, and from HRM practices to individual-level performance, are significant. The direct path from 
HRM to performance is not significant. Taken together, this analysis provides further support for hypotheses 1a, 2 and $3 a$.

\section{INSERT TABLE 7 ABOUT HERE}

\section{Unit-level performance}

Table 8 shows the path coefficients and fit indices for this relationship. Again, as shown in the base model, the direct paths from HRM to trust in organization, and from trust as the mediator to unit-level performance, are both significant, and in the directions hypothesized. The indices show a good fit for the base model (RMSEA $=0.056$; GFI, CFI, NNFI and IFI between 0.896 and 0.910). The direct-effect model shows a significant association between HRM and performance, with a good fit (RMSEA = 0.058; GFI, CFI, NNFI and IFI between 0.886 and 0.902).

The model statistics reveal good fit indices for the partial mediation model (RMSEA = 0.058; GFI, CFI, NNFI and IFI between 0.886 and 0.902). The partial mediation model shows that the paths from HRM practices to trust in organization, and from the mediator to unit-level performance, are significant. However, the path from HRM to performance is not significant. In sum, Study 2 confirms support for hypotheses $1 b, 2$ and $3 b$ : trust in organization is a full mediator between HRM and unit-level performance. 


\section{INSERT TABLE 8 ABOUT HERE}

\section{Organization-level performance}

For the path coefficients and fit indices for this relationship, please see Table 9. The base model paths are significant and in the directions hypothesized. Moreover, the indices show a good fit for the base model (RMSEA $=0.052$; GFI, CFI, NNFI and IFI between 0.899 and 0.914). The direct-effect model also exhibits a significant association between HRM and organization-level performance, with adequate fit (RMSEA $=0.058$; GFI, CFI, NNFI and IFI between 0.878 and 0.906).

The model statistics also reveal good fit indices for the partial mediation model $($ RMSEA $=0.052$; GFI, CFI, NNFI and IFI between 0.900 and 0.915). The paths from HRM practices to trust in organization and from this mediator to performance are significant. However, again, the path from HRM to organization-level performance is not significant. Taken together, these results from Study 2 affirm support for hypotheses 1c, 2 and 3c: trust in organization fully mediates the effect of HRM practices on organization-level performance.

INSERT TABLE 9 ABOUT HERE 
Interestingly, much more of the variation in performance is explained by the full mediation model at the unit-level and organization-level. The coefficient of determination accounted for more than a third of variance at the unit-level (Study $1=$ $31.4 \%$; Study $2=34.4 \%$ ), and a significant amount at the organization-level (Study $1=$ $46.1 \%$; Study $2=28 \%$ ), but at the individual level, the coefficient of determination was low (Study $1=2.5 \%$; Study $2=5.8 \%$ ). This suggests that HRM practices appear to affect performance through trust in the organization primarily at these two levels. Figures 1 and 2 summarise the path coefficients for both studies.

INSERT FIGURES 1 AND 2 HERE.

\section{DISCUSSION AND CONCLUSION}

It is increasingly recognized that there is an institutional, or impersonal, dimension to employees' trust in their employer organization: employees not only place, or withhold, trust in their top management team as a unit representing the interests of the organization and determining its direction; they also (dis)trust their organization as a functional structure (e.g. its strategy, vision and policies and processes, including its HRM). Research on trust has not analyzed this impersonal trust comprehensively, with 
little research into its role. We theorized that a focus on this particular relationship for employees' trust is critical for effective HRM, and that this relationship is influenced significantly by the HRM practices adopted by an organization, through the creation and maintenance of a productive social exchange. We also theorized why trust in employer should be relevant for performance. From this, we developed nine hypotheses. The first three (1a-1c) suggested, in accordance with earlier research, that HRM would be positively related to performance; the second hypothesis suggested that HRM would be positively associated with employees' trust in organization, and the third set of hypotheses (3a-3c) suggested that the effect of HRM on performance would be fully mediated by employees' trust in organization. Two studies from the forestry (411 employees) and ICT (304 employees) industries in Finland validated all our hypotheses, including the mediating role of trust in employer.

This study contributes to two literatures. The first contribution is to the growing number of studies on the role of trust in the context of intra-organizational relationships, and especially at the organizational level. The second is to the established literature on the link between HRM and performance. A significant contribution of this study is to unlock HRM's 'black box', by identifying a theoretically plausible and empirically compelling path through which HRM delivers superior employee performance via the mediator of employees' trust in their employer organization. The results from two very 
different organizations confirm that this path is positive. At the individual, unit-level and organization-levels of performance, HRM's impact is realized fully through employees' trust in their employer, as an organization. The results do suggest that if HRM can be designed specifically to enhance employees' trust in their organization, its effect on performance is positive.

One explanation for the differences in variation explained at the different levels of performance may be that HR practices tend to be designed and implemented to operate at the unit- and organization-levels, and so these links may be more apparent to employees than at the individual level, where employee performance is a more idiosyncratic affair less obviously shaped by HRM. This explanation is in fact fully in line with our theorizing, which argues that employees perceive HRM practices as sending signals about the trustworthiness of their employer. It could also be that at the individual level, the actions of supervisors and managers wield more influence on performance. In other words, interpersonal trust (i.e. between employees and managers as individuals) may account for more of individual-level performance, whereas trust in the organization pertains more at higher hierarchical levels.

It is notable that the findings were quite similar in both studies, even though the demographics differed markedly in terms of age, education and tenure. These control 
variables did not have any effect on how HRM affects performance. This could be explained within the context of Finland, where people's propensity to trust in general is quite high and there is unlikely to be major differences between industries or between different kinds of employer. However based on our study it could be assumed HRM affects performance through trust in employer organization similarly in different kind of industries and among different kind of employee groups.

\section{LIMITATIONS AND FURTHER RESEARCH}

As well as general methodological caveats on single-respondent data, the possibility of common method variance, and the extent to which a single study can be generalized beyond its context, there is the possibility of reverse causality, in that employees' trust in their employer may explain their assessments of the HRM practices (Tzafrir, 2005). Longitudinal studies such as Mayer and Davis (1999) are valued for their implications on cause and effect.

Our measures for performance are subjective, as objective measures of performance were not available. Additionally, our measure for organization-level performance had a relatively low Cronbach's alpha. Although subjective assessments of performance do correlate well with objective performance data, future studies incorporating objective

performance data would further enhance our understanding of the HRM-trust- 
performance relationships. Separate raters for HRM and trust on the one hand, and performance on the other, would of course resolve concerns over common method variance.

Finally, the role of trust in the HRM-performance linkage is not limited only to trust in employer. As the literature attests, HRM practices can also be designed and used to build interpersonal trust relations, as well, among, for example, trust in immediate line manager, and among colleagues. Though we would reiterate our arguments about the primacy of trust in the organization, and we believe that HRM's signals are more informative on this relationship than on these more interpersonal relations, future studies could explore multiple interpersonal trust relations alongside trust in the organization. Then it would be possible to test a model of the relationships between HRM practices, different trust relationships and performance, to see which trust relationships are most influenced by HRM, which trust relationships matter for employee behavior and performance (see Redman \& Snape, 2005, for a similar study using commitment), and the extent of complementarity between interpersonal and impersonal forms of workplace trust.

\section{PRACTICAL IMPLICATIONS FOR MANAGERS}


Our findings provide new insights into the nature of organizational trust, and particularly the impersonal dimension, not only for academics but for practitioners, especially those in HR. The evidence from these two studies is that HR policies can enhance employees' trust towards their employer, and through this, can enhance the performance of the organization. Yet this is not - or should not be - a matter of interest only for the HR function. High internal trust adds value, is rare, and hard to imitate or replace, and therefore can be a source of sustainable competitive advantage (Barney \& Hansen, 1994). Enhancing employees' trust in their employing organization is a strategic concern for the whole management cadre.

One practical implication, therefore, is to consider a trust audit of HRM, identifying and modifying the signals sent by each HR policy about the employer's ability, benevolence and integrity (e.g. the accuracy and fairness of the appraisal system; the expectations created by the firm's recruitment materials and induction process; the honesty of the internal communications), as well as what the employer considers a useful display of the same attributes from employees (e.g. performance standards; ethical conduct; support for colleagues). Changes to policies and practice can be expected to have repercussions on employees' trust, and given that trust can be such a precious internal resource, these need to be borne carefully in mind. Another would be to incorporate 'trust in the 
employer organization' measures into staff attitude surveys. A practical advantage of this particular construct is that it is more neutral than tracking interpersonal relations. 


\section{REFERENCES}

Adler, P. (2001). 'Market, hierarchy, and trust: The knowledge economy and the future of capitalism'. Organization Science, 12 (2), 215-234.

Alvesson, M. (2004), 'Knowledge Work and Knowledge-Intensive Firms'. Oxford University Press Inc, New York.

Anderson, J.C. and Gerbing, D.W. (1988) 'Structural Equation Modeling in Practice: A Review and Recommended Two-Step Approach'. Psychological Bulletin, 103 (3), 411423.

Armstrong, J.S. and Overton, T.S. (1977). 'Estimating Nonresponse Bias in Mail Surveys'. Journal of Marketing Research, 14, 396-402.

Aryee, S., Budhwar, P. and Chen, Z (2002). 'Trust as a mediator of the relationship between organizational justice and work outcomes: test of a social exchange model'. Journal of Organizational Behaviour 23, 267-285. 
Barney, J.B, \& Hansen, M.H (1994). 'Trustworthiness as a source of competitive advantage'. Strategic Management Journal, 15, 175-190

Baron, R.M \& Kenny, D.A (1986). 'The moderator-mediator variable distinction in social psychological research: conceptual, strategic, and statistical considerations'. Journal of Personality and Social Psychology, 51 (6), 1173-1182

Blomqvist, K. (1997). 'The many faces of trust'. Scandinavian Journal of Management, $13,271-286$.

Boselie, P., Dietz, G. and Boon, C. (2005). 'Commonalities and contradictions in HRM and performance research'. Human Resource Management Journal, 15(3), 1-29.

Combs, J., Liu, Y., Hall, A and Ketchen, D (2006). 'How much do high-performance work practices matter? A meta-analysis of their effects on organizational performance'. Personnel Psychology, 59, 501-528

Colquitt, J.A., Scott, B.A. \& LePine, L.A (2007). 'Trust, trustworthiness, and trust propensity: A meta-analytic test of their unique relationships with risk taking and job performance'. Journal of Applied Psychology, 92 (4), 909-927 
Costigan, R.D., Ilter, S.S. and Berman, J.J. (1998). 'A multi-dimensional study of trust in organisations'. Journal of Managerial Issues, 10, 303-317.

Coyle-Shapiro, J.A-M. \& Conway, N (2004). 'The employment relationship through the lens of social exchange', in Coyle-Shapiro, J.A-M., Shore, L.M., Taylor, S \& Tetrick, L.E (ed): 'The employment relationship: examining psychological and contextual perspectives'. Oxford: OUP

Cropanzano, R \& Mitchell. M.S. (2005). 'Social Exchange Theory: An Interdisciplinary Review'. Journal of Management, 31 (6), 874-900.

Davis, J.H., Schoorman, F.D., Mayer, R.C., \& Tan, H.H. (2000). 'The trusted general manager and business unit performance: Empirical evidence of a competitive advantage'. Strategic Management Journal, 21, 563-576.

Delaney, J.T. \& Huselid, M.A. (1996). 'The impact of human resource management practices on perceptions of organizational performance'. Academy of Management Journal, 39, 949-969. 
Delery, J. E. (1998). 'Issues of fit in strategic human resource management: Implications for research'. Human Resource Management Review, 289-309.

Delery, J.E. \& Doty, D.H. (1996). 'Modes of theorizing in strategic human resource management: Tests of universalistic, contingency, and configurational performance predictions'. Academy of Management Journal, 39, 802-835.

Demartini, C. (2015). 'Relationships between Social and Intellectual Capital: Empirical Evidence from IC Statements'. Knowledge and Process Management, 22 (2), 99-111.

Dietz, G \& den Hartog, D (2006). 'Measuring trust inside organizations'. Personnel Review, 35 (5), 557-588

Dirks K.T. \& Ferrin D.L. (2001). 'The Role of Trust in Organisational Settings'. Organization Science, 12(4): 450-467.

Drucker, P. (2001). 'The Next Society: A Survey of the Near Future'. The Economist, November (3), 2-20. 
Dvir, D. \& Shenhar, A. (1992). 'Measuring the Success of Technology-Based Strategic Business Units'. Engineering Management Journal, 4 (4), 33-38.

Farndale, E., van Ruiten, J., Kelliher, C \& Hope-Hailey, V (2011). 'The influence of perceived employee voice on organizational commitment: an exchange perspective'. Human Resource Management, 50 (1), 113-129

Ford, D. P. (2004). 'Trust and Knowledge Management: The Seeds of Success' in C. W. Holsapple (ed.), Handbook on Knowledge Management 1: 553-575. Springer-Verlag: Berlin Heidelberg.

Gillespie, N \& Dietz, G (2009). 'Trust repair after an organization-level failure'. Academy of Management Review, 34 (1), 127-145.

Gould-Williams, J. (2003). 'The importance of HR practices and workplace trust in achieving superior performance: a study of public-sector organizations'. International Journal of Human Resource Management, 14 (1), 28-54. 
Gould-Williams, J. (2007). 'HR Practices, organisational climate and employee outcomes: evaluating social exchange relationships in local government organisations'. International Journal of Human Resource Management, 18 (9), 1627-1647.

Guest, D.E. (1997). 'Human resource management and performance: a review and research agenda'. International Journal of Human Resource Management, 8 (3), 265276.

Guest, D.E. (1999). 'Human resource management: the workers' verdict'. Human Resource Management Journal, 9 (3), 5-25.

Hair, J.F., Black, W.C., Rabin, B.J., Anderson, R.E. and Tatham, R.L. (2006), 'Multivariate data analysis $-6^{\text {th }}$ ed'. New Jersey: Pearson Education.

Holsapple, C. and Joshi, K. (2000) 'An Investigation of Factors that Influence the Management of Knowledge in Organizations'. Journal of Strategic Information Systems, 9, 235-261.

Inkinen, H. (2015). 'Review of empirical research on intellectual capital and firm performance'. Journal of Intellectual Capital, 16 (3), 518-565. 
Inkinen, H., Kianto, A. and Vanhala, M. (2015). 'Knowledge Management Practices and Innovation Performance in Finland'. Baltic Journal of Management, 10 (4), 432455.

Kianto, A., Ritala, P., Spender, JC. and Vanhala, M. (2014). 'The interaction of intellectual capital assets and knowledge management practices in organizational value creation'. Journal of Intellectual Capital, 15 (3), 362-375.

Kuvaas, B. (2008). 'An Exploration of How the Employee-Organization Relationship Affects the Linkage Between Perception of Developmental Human Resource Practices and Employee Outcomes'. Journal of Management Studies, 45 (1), 1-25.

Lane, C. \& Bachmann, R. (1998). 'Trust within and between organizations: conceptual issues and empirical applications'. Oxford: Oxford University Press.

Lewicki, R., McAllister, D., and Bies, R. (1998). 'Trust and distrust: New relationships and realities'. Academy of Management Review, 23, 438-458. 
Maguire, S. and Phillips, N. (2008). “Citibankers' at Citigroup: A Study of the Loss of Institutional Trust after a Merger'. Journal of Management Studies, 45, 372-401.

Mayer, R.C., Davis, J.H. \& Schoorman, F.D (1995). 'An integrative model of organizational trust'. Academy of Management Review, 20 (3), 709-734.

Mayer, R.C. and Davis, J.H (1999). 'The effect of the performance appraisal system on trust for management: a field quasi-experiment'. Journal of Applied Psychology, 84 (1), 123-136.

McCauley, D.P. and Kuhnert, K.W. (1992), 'A theoretical review and empirical investigation of employee trust in management' Public Administration Quarterly, 16, $265-284$.

Morgan, D. and Zeffane, R. (2003). 'Employee involvement, organizational change and trust in management'. The International Journal of Human Resource Management, 14 (1), 55-75.

Neve, P. and Caetano, A. (2006). 'Social Exchange Process in Organizational Change: The Roles of Trust and Control'. Journal of Change Managemenet, 6 (4), 351-364. 
Olander, H., Vanhala, M. Hurmelinna-Laukkanen, P. and Blomqvist, K. (2015). 'HRrelated knowledge protection and innovation performance: The moderating effect of trust'. Knowledge and Process Management, 22 (3), 220-233.

Ozlati, S. (2015). 'The Moderating Effect of Trust on the Relationship between Autonomy and Knowledge Sharing: A National Multiindustry Survey of Knowledge Workers'. Knowledge and Process Management, 22 (3), 191-205.

Pauuwe, J (2009). 'HRM ad performance: Achievements, methodological issues and prospects'. Journal of Management Studies, 46 (1), 129-142

Pearce, J.L., Branyiczki, I. and Bigley, G.A. (2000). 'Insufficient Bureaucracy: Trust and Commitment in Particularistic Organizations'. Organization Science, 11, 148-162.

Podsakoff, P.M., MacKenzie, S.B., Lee, J-Y., and Podsakoff, N.P. (2003). 'Common Method Biases in Behavioral Research: A Critical Review of the Literature and Recommended Remedies'. Journal of Applied Psychology, 88, 879-903. 
Politis, J. D. (2003). 'The connection between trust and knowledge management: what are its implications for team performance'. Journal of Knowledge Management, 7 (5), $55-66$.

Redman, T and Snape, E (2005). 'Unpacking commitment: multiple loyalties and employee behaviour'. Journal of Management Studies, 42: 301-328.

Redman, T., Dietz, G., van der Borg, W and Snape, E (2011). 'Trust in the workplace: A multiple constituencies approach'. International Journal of Human Resource Management, 22 (11), 2384-2402.

Roberts, J. (2000). 'From Know-How to Show-How? Questioning the Role of Information and Communication Technologies in Knowledge Transfer'. Technology Analysis and Strategic Management, 12 (4), 429-443.

Robinson, S.L. (1996). 'Trust and breach of the psychological contract'. Administrative Science Quarterly, 41, 574-599. 
Robinson, R.B. and Pearce, J. A. (1988). 'Planned patterns of strategic behaviour and their relationship to business-unit performance'. Strategic Management Journal, 9 (1), 43-60.

Robinson, S.L. \& Rousseau, D.M. (1994). 'Violating the psychological contract: not the exception but the norm'. Journal of Organizational Behavior, 15 (3), 245-259.

Rousseau, D.M., Sitkin, S.B., Burt, R.S., \& Camerer, C.F. (1998). 'Introduction to special topic forum: not so different after all: a cross-discipline view of trust'. Academy of Management Review, 23 (3), 393-404.

Salamon, S.D \& Robinson, S.L (2008). 'Trust That Binds: The Impact of Collective Felt Trust on Organizational Performance'. Journal of Applied Psychology, 93 (3), 593601.

Saunders, M. N. K. and Thornhill, A. (2003). 'Organisational justice, trust and the management of change: An exploration'. Personnel Review, 32 (3), 360-375.

Searle, R., den Hartog, D., Weibel, A., Gillespie, N, Six, F, Hatzakis, T \& Skinner, D. (2011). 'Trust in the employer: the role of high-involvement work practices and 
procedural justice in European organisations'. International Journal of Human Resource Management, 22 (5), 1069-1092.

Searle, R., \& Skinner, D. (Eds.). (2011). 'Trust and HRM'. Chichester: Edward Elgar.

Settoon, R., Nathan, B and Liden, R (1996). 'Social exchange in organizations: perceived organizational support, leader-member exchange, and employee reciprocity'. Journal of Applied Psychology 81: 219-227.

Simons, T (2002). 'The high cost of low trust'. Harvard Business Review, September, 18-19.

Snape, E and Redman, T (2010). 'HRM practices, organizational citizenship behaviour, and performance: A multi-level analysis'. Journal of Management Studies, 47 (7), 12191247

Tan, H.H. and Tan, C.S.F. (2000). 'Toward the Differentiation of Trust in Supervisor and Trust in Organization'. Genetic, Social, and General Psychology Monographs, 162, 241-260. 
Tzafrir, S.S., Harel, G.H., Baruch, Y. and Dolan, S.L. (2004). 'The consequences of emerging HRM practices for employees' trust in their managers'. Personnel Review, 33, 628-647.

Tsui, A., Pearce, J., Porter, L. \& Tripoli, A. (1997). 'Alternative approaches to the employee-organization relationship: does investment in employees pay off?' Academy of Management Journal, 40 (5), 1089-1121.

Tsui, A. and Wu, J. (2005). 'The new employment relationship versus the mutual investment approach: implications for human resource management'. Human Resource Management, 44 (2), 115-121.

Vanhala, M., Puumalainen, K. \& Blomqvist, K. (2011). 'Impersonal trust - the development of the construct and the scale'. Personnel Review, 40 (4), 485-513.

Wall, T. \& Wood, S. (2005). 'The romance of human resource management and business performance, and the case for big science'. Human Relations, 58(4), 429-462.

Whitener, E. (1997). 'The impact of human resource activities on employee trust'. Human Resource Management Review, 7 (4), 389-404. 
Whitener, E. (2001). 'Do 'high commitment' human resource practices affect employee commitment? A cross-level analysis using hierarchical liner modeling'. Journal of Management, 27, 515-535.

Whitener, E., Brodt, S., Korsgaard, M and Werner, J (1998). 'Managers as initiators of trust: an exchange relationship framework for understanding managerial trustworthy behaviour'. Academy of Management Review, 23 (3), 513-30

Whitley, R (1987). 'Taking firms seriously as economic actors: Towards a sociology of firm behaviour'. Organization Studies, 8, 125-147

Wright, P. \& Boswell, W. (2002). 'Desegregating HRM: a review and synthesis of micro and macro human resource management research'. Journal of Management, 28 (3), 247-276.

Wood, S. (1999). 'Human resource management and performance'. International Journal of Management Reviews, 1:4, 367-413. 
Zeffane, R and Connell, J (2003). 'Trust and HRM in the new millennium'. International Journal of Human Resource Management, 14 (1), 3-11.

Zhang, A.Y., Tsui, A., Song, L.J, Li, C \& Jia, L (2008). 'How do I trust thee? The employee-organization relationship, supervisory support, and middle manager trust in the organisation'. Human Resource Management, 47 (1), 111-132. 
Table 1: Profile of the respondents in both organizations.

\begin{tabular}{|l|c|c|}
\hline & $\begin{array}{c}\text { FORESTRY } \\
\text { COMPANY }\end{array}$ & $\begin{array}{c}\text { ICT } \\
\text { COMPANY }\end{array}$ \\
\hline Gender & 79.3 & 84.9 \\
Wen & 18 & 14.8 \\
\hline Age & 7.8 & 21.1 \\
\hline 31-30 & 23.4 & 53.3 \\
$41-50$ & 39.9 & 21.1 \\
51-60 & 25.8 & 2.3 \\
\hline Education & & \\
\hline Vocational education & 63 & 2.3 \\
Further education qualification & 8.5 & 39.1 \\
Higher education qualification & 4.9 & 45.1 \\
\hline Tenure & & \\
Less than 10 years & 0.2 & 78.9 \\
11-15 years & 14.4 & 11.2 \\
16-20 years & 13.6 & 3.3 \\
More than 20 years & 52.3 & 6.3 \\
\hline Job position & & \\
Employees & 72.5 & 80.6 \\
'Officials' & 14.8 & 2.9 \\
Team Leaders & 6.1 & - \\
Managers & 3.6 & 16.1 \\
\hline
\end{tabular}


Table 2: Correlation matrix: study 1

\begin{tabular}{|c|c|c|c|c|c|c|c|c|c|c|c|c|c|}
\hline Construct & Mean & SD & 1 & 2 & 3 & 4 & 5 & 6 & 7 & 8 & 9 & 10 & 11 \\
\hline 1 1 Gender & 1.82 & (.39 & & & & & & & & & & & \\
\hline 2 Age & 3.90 & .93 & $-.114 *$ & & & & & & & & & & \\
\hline 3 Education & 2.58 & 1.43 & $-.198 * *$ & -.093 & & & & & & & & & \\
\hline 4 Job tenure & 4.96 & 1.30 & .059 & $.691 * *$ & $-.132 * *$ & & & & & & & & \\
\hline 5 Position & 1.47 & .93 & -.025 & .076 & $.483 * *$ & -.002 & & & & & & & \\
\hline 6 Unit & 4.34 & 2.35 & $-.145 * *$ & .010 & .069 & -.071 & .024 & & & & & & \\
\hline $\begin{array}{l}7 \text { Individual } \\
\text { performance }\end{array}$ & 4.16 & .66 & -.011 & -.055 & -.034 & -.031 & -.060 & -.009 & $(.75)$ & & & & \\
\hline $\begin{array}{l}8 \text { Unit-level } \\
\text { performance }\end{array}$ & 3.69 & .70 & .035 & .019 & .030 & .071 & .061 & .050 & $.244 * *$ & $(.75)$ & & & \\
\hline $\begin{array}{l}9 \text { Organization-level } \\
\text { performance }\end{array}$ & 3.71 & .59 & .082 & -.080 & -.007 & .054 & .061 & .040 & $.182 * *$ & $.464 * *$ & $(.59)$ & & \\
\hline $10 \mathrm{HRM}$ practices & 3.15 & .69 & -.047 & .001 & .038 & .018 & $.116 *$ & -.041 & $.150 * *$ & $.408 * *$ & $.461 * *$ & $(.84)$ & \\
\hline $\begin{array}{l}11 \text { Trust in } \\
\text { organization }\end{array}$ & 3.16 & .65 & -.033 & -.035 & $.098 *$ & -.023 & $.172 * *$ & -.042 & $.203 * *$ & $.530 * *$ & $.551 * *$ & $.671 * *$ & $(.78)$ \\
\hline
\end{tabular}

* indicates statistically significant correlation at the .05 level; ** indicates statistically significant correlation at the .01 level. Cronbach's alphas are presented in parentheses on the diagonal 
Table 3: The fit indices and path coefficients of the individual performance models: study 1

\begin{tabular}{lccc} 
Path model & $\begin{array}{c}\text { Base model } \\
\text { Standardized } \\
\text { coefficient }\end{array}$ & $\begin{array}{c}\text { Direct effect } \\
\text { Standardized } \\
\text { coefficient }\end{array}$ & $\begin{array}{c}\text { Partial } \\
\text { mediation } \\
\text { Standardized } \\
\text { coefficient }\end{array}$ \\
\hline \hline HRM $\rightarrow$ Trust in organization & $.827^{* * *}$ & & $.829^{* * *}$ \\
Trust in organization $\rightarrow$ Individual performance & $.188^{* * *}$ & & -.098 n.s. \\
HRM $\rightarrow$ Individual performance & & & \\
Control variable effect & & $.150^{* *}$ & -.023 n.s. \\
Employment duration $\rightarrow$ Individual performance & -.025 n.s. & -.030 n.s. & \\
Overall fit & & & $287.01(148)$ \\
Chi-square (df) & $286.63(149)$ & $287.94(148)$ & .048 \\
RMSEA & .047 & .048 & .931 \\
GFI & .931 & .931 & .936 \\
CFI & .936 & .934 & .926 \\
NNFI & .926 & .924 & .936 \\
IFI & .937 & .935 & .018 \\
$R^{2}$ & .025 & .023 &
\end{tabular}

$* \mathrm{p}<0.05 ; * * \mathrm{p}<0.01 ; * * * \mathrm{p}<0.005$. 
Table 4: The fit indices and path coefficients of the unit-level performance models: study 1

\begin{tabular}{lccc}
\multicolumn{1}{c}{ Path model } & $\begin{array}{c}\text { Base model } \\
\text { Standardized } \\
\text { coefficient }\end{array}$ & $\begin{array}{c}\text { Direct effect } \\
\text { Standardized } \\
\text { coefficient }\end{array}$ & $\begin{array}{c}\text { Partial } \\
\text { mediation } \\
\text { Standardized } \\
\text { coefficient }\end{array}$ \\
\hline \hline HRM $\rightarrow$ Trust in organization & $.817^{* * *}$ & $.828^{* * *}$ \\
Trust in organization $\rightarrow$ Unit-level performance & $.675^{* * *}$ & $.855^{* * *}$ \\
HRM $\rightarrow$ Unit-level performance & & & -.195 n.s. \\
Control variable effect & & $.572^{* * *}$ & $.108^{*}$ \\
Employment duration $\rightarrow$ Unit-level performance & & & \\
Overall fit & $.105^{*}$ & .086 n.s. & $291.74(166)$ \\
Chi-square (df) & & & .043 \\
RMSEA & $294.36(167)$ & $337.5(166)$ & .934 \\
GFI & .043 & .050 & .945 \\
CFI & .933 & .924 & .937 \\
NNFI & .944 & .928 & .945 \\
IFI & .936 & .917 & .275 \\
$R^{2}$ & .945 & .928 & .335 \\
p $_{\mathrm{p}}<0.05 ; * \mathrm{p}<0.01 ; * * * \mathrm{p}<0.005$. & .314 & &
\end{tabular}


Table 5: The fit indices and path coefficients of the organization-level performance models: study 1

\begin{tabular}{|c|c|c|c|}
\hline Path model & $\begin{array}{c}\text { Base model } \\
\text { Standardized } \\
\text { coefficient }\end{array}$ & $\begin{array}{l}\text { Direct effect } \\
\text { Standardized } \\
\text { coefficient }\end{array}$ & $\begin{array}{c}\text { Partial } \\
\text { mediation } \\
\text { Standardized } \\
\text { coefficient } \\
\end{array}$ \\
\hline HRM $\rightarrow$ Trust in organization & $.815 * * *$ & & $.829 * * *$ \\
\hline $\begin{array}{l}\text { Trust in organization } \rightarrow \text { Organization-level } \\
\text { performance }\end{array}$ & $.827 * * *$ & & $1.012 * * *$ \\
\hline HRM $\rightarrow$ Organization-level performance & & $.713 * * *$ & -.199 n.s. \\
\hline $\begin{array}{l}\text { Control variable effect } \\
\text { Employment duration } \rightarrow \text { Organization-level } \\
\text { performance }\end{array}$ & .081 n.s. & .058 n.s. & .084 n.s. \\
\hline Overall fit & & & \\
\hline Chi-square (df) & $280.21(149)$ & $328.28(148)$ & $279.98(148)$ \\
\hline RMSEA & .046 & .055 & .047 \\
\hline GFI & .933 & .922 & .933 \\
\hline CFI & .938 & .915 & .939 \\
\hline NNFI & .929 & .901 & .929 \\
\hline IFI & .939 & .916 & .940 \\
\hline$R^{2}$ & .461 & .513 & .416 \\
\hline
\end{tabular}


Table 6: Correlation matrix: study 2

\begin{tabular}{|c|c|c|c|c|c|c|c|c|c|c|c|c|c|}
\hline Construct & Mean & SD & 1 & 2 & 3 & 4 & 5 & 6 & 7 & 8 & 9 & 10 & 11 \\
\hline 1 Gender & 1.85 & .37 & & & & & & & & & & & \\
\hline 2 Age & 3.00 & .79 & $.223 * *$ & & & & & & & & & & \\
\hline 3 Education & 4.38 & 1.04 & $.145^{*}$ & $.223 * *$ & & & & & & & & & \\
\hline 4 Job tenure & 2.61 & 1.36 & .063 & $.481 * *$ & .050 & & & & & & & & \\
\hline 5 Position & 1.27 & .78 & -.83 & $.135 *$ & -.021 & .053 & & & & & & & \\
\hline 6 Unit & 9.39 & 4.03 & $.174 * *$ & .013 & $.343^{* *}$ & $-.222 * *$ & .062 & & & & & & \\
\hline 7 Individual performance & 3.96 & .72 & -.011 & $-.140 *$ & .031 & -.060 & -.036 & -.071 & $(.74)$ & & & & \\
\hline 8 Unit-level performance & 3.50 & .78 & -.026 & .007 & -.054 & -.029 & .070 & .003 & $.237 * *$ & $(.78)$ & & & \\
\hline 9 Organization-level performance & 3.61 & .63 & -.087 & .031 & -.074 & .015 & .033 & .022 & $.175 * *$ & $.522 * *$ & $(.65)$ & & \\
\hline $10 \mathrm{HRM}$ practices & 3.38 & .67 & .044 & -.014 & -.065 & -.057 & .022 & .053 & $.194 * *$ & $.470 * *$ & $.369 * *$ & $(.81)$ & \\
\hline 11 Trust in organization & 3.31 & .63 & .008 & -.018 & -.092 & -.041 & .004 & -.013 & $.249 * *$ & $.513 * *$ & $.475 * *$ & $.666 * *$ & $(.76)$ \\
\hline
\end{tabular}

* indicates statistically significant correlation at the .05 level; ** indicates statistically significant correlation at the .01 level

Cronbach's alphas are presented in parentheses on the diagonal 
Table 7: The fit indices and path coefficients of the individual performance models: study 2

\begin{tabular}{lccc} 
Path model & $\begin{array}{c}\text { Base model } \\
\text { Standardized } \\
\text { coefficient }\end{array}$ & $\begin{array}{c}\text { Direct effect } \\
\text { Standardized } \\
\text { coefficient }\end{array}$ & $\begin{array}{c}\text { Partial mediation } \\
\text { Standardized } \\
\text { coefficient }\end{array}$ \\
\hline HRM $\rightarrow$ Trust in organization & $.827^{* * *}$ & & $.831^{* * * *}$ \\
Trust in organization $\rightarrow$ Individual performance & $.285^{* * *}$ & $.480^{* * * *}$ \\
HRM $\rightarrow$ Individual performance & & $.227^{* * *}$ & -.212 n.s. \\
Control variable effect & & & \\
Employment duration $\rightarrow$ Individual performance & -.038 n.s. & -.039 n.s. & -.004 n.s. \\
Overall fit & & & \\
Chi-square (df) & $277.2(148)$ & $283.5(148)$ & $275.78(148)$ \\
RMSEA & .053 & .055 & .053 \\
GFI & .912 & .910 & .913 \\
CFI & .911 & .907 & .912 \\
NNFI & .898 & .892 & .898 \\
IFI & .913 & .908 & .913 \\
$R^{2}$ & .058 & .054 & .038
\end{tabular}

$* \mathrm{p}<0.05 ; * * \mathrm{p}<0.01 ; * * * \mathrm{p}<0.005$. 
Table 8: The fit indices and path coefficients of the unit-level performance models: study 2

\begin{tabular}{lccc} 
Path model & $\begin{array}{c}\text { Base model } \\
\text { Standardized } \\
\text { coefficient }\end{array}$ & $\begin{array}{c}\text { Direct effect } \\
\text { Standardized } \\
\text { coefficient }\end{array}$ & $\begin{array}{c}\text { Partial mediation } \\
\text { Standardized } \\
\text { coefficient }\end{array}$ \\
\hline \hline HRM $\rightarrow$ Trust in organization & $.842^{* * *}$ & & $.830^{* * * *}$ \\
Trust in organization $\rightarrow$ Unit-level performance & $.699 * * *$ & $.551^{* * *}$ \\
HRM $\rightarrow$ Unit-level performance & & & .158 n.s. \\
Control variable effect & & $.660 * * *$ & .027 n.s. \\
Employment duration $\rightarrow$ Unit-level performance & .024 n.s. & .031 n.s. & \\
Overall fit & & & $323.14(166)$ \\
Chi-square (df) & $325.22(167)$ & $335.31(166)$ & .056 \\
RMSEA & .056 & .058 & .904 \\
GFI & .903 & .900 & .908 \\
CFI & .908 & .901 & .895 \\
NNFI & .896 & .886 & .910 \\
IFI & .910 & .902 & .377 \\
$R^{2}$ & .344 & .433 &
\end{tabular}


Table 9: The fit indices and path coefficients of the organization-level performance models: study 2

\begin{tabular}{lccc}
\multicolumn{1}{c}{ Path model } & $\begin{array}{c}\text { Base model } \\
\text { Standardized } \\
\text { coefficient }\end{array}$ & $\begin{array}{c}\text { Direct effect } \\
\text { Standardized } \\
\text { coefficient }\end{array}$ & $\begin{array}{c}\text { Partial mediation } \\
\text { Standardized } \\
\text { coefficient }\end{array}$ \\
\hline \hline HRM $\rightarrow$ Trust in organization & $.816^{* * *}$ & & $.831^{* * *}$ \\
Trust in organization $\rightarrow$ Organization-level performance & $.649^{* * *}$ & & $.911^{* * *}$ \\
HRM $\rightarrow$ Organization-level performance & & & -.287 n.s. \\
Control variable effect & & $.553 * * *$ & .076 n.s. \\
Employment duration $\rightarrow$ Organization-level performance & .080 n.s. & .080 n.s. & \\
Overall fit & & & $270.65(148)$ \\
Chi-square $(\mathrm{df})$ & $273.07(149)$ & $300.12(148)$ & .052 \\
RMSEA & .052 & .058 & .914 \\
GFI & .913 & .906 & .914 \\
CFI & .912 & .894 & .900 \\
NNFI & .899 & .878 & .915 \\
IFI & .914 & .896 & .221 \\
$R^{2}$ & .280 & .305 & \\
$* \mathrm{p}<0.05 ; * \mathrm{p}<0.01 ; * * * \mathrm{p}<0.005$. & & &
\end{tabular}




\section{Appendix 1: Measurement items: study 1.}

\begin{tabular}{|c|c|c|c|c|c|c|}
\hline CONSTRUCT & ITEM & MEAN & SD & $\begin{array}{l}\text { FACTOR } \\
\text { LOADING }\end{array}$ & CR & $\alpha$ \\
\hline \multirow{3}{*}{$\begin{array}{r}\text { INDIVIDUAL } \\
\text { PEFORMANCE }\end{array}$} & I am satisfied with my work performance. & 4.34 & .748 & $.796^{\mathrm{a}}$ & \multirow{3}{*}{.77} & \multirow{3}{*}{.75} \\
\hline & $\begin{array}{l}\text { My employer is satisfied with my work } \\
\text { performance. }\end{array}$ & 3.92 & .885 & $.566^{* * *}$ & & \\
\hline & $\begin{array}{l}\text { I am satisfied with my work performance } \\
\text { compared to that of other employees who do the } \\
\text { same kind of job. }\end{array}$ & 4.22 & .780 & $.807^{* * *}$ & & \\
\hline \multirow{4}{*}{$\begin{array}{l}\text { UNIT-LEVEL } \\
\text { PERFORMANCE }\end{array}$} & $\begin{array}{l}\text { My unit has been successful in advancing and } \\
\text { supporting new business opportunities. }\end{array}$ & 3.70 & .901 & $.683^{\mathrm{a}}$ & \multirow{4}{*}{.75} & \multirow{4}{*}{.75} \\
\hline & $\begin{array}{l}\text { My unit has prepared well for future } \\
\text { opportunities and challenges. }\end{array}$ & 3.55 & .952 & $.676^{* * *}$ & & \\
\hline & $\begin{array}{l}\text { My unit has the relevant scientific, technical and } \\
\text { professional knowledge to cope with future } \\
\text { needs. }\end{array}$ & 3.87 & .887 & $.667^{* * *}$ & & \\
\hline & $\begin{array}{l}\text { My unit has adequate people and skills to convert } \\
\text { ideas into new products and services, and to } \\
\text { produce and implement them. }\end{array}$ & 3.62 & .974 & $.60^{* * * *}$ & & \\
\hline \multirow{4}{*}{$\begin{array}{l}\text { ORGANIZATION- } \\
\text { LEVEL } \\
\text { PERFORMANCE }\end{array}$} & $\begin{array}{l}\text { How would you compare your organization's } \\
\text { performance over the past } 3 \text { years to that of other } \\
\text { successful organizations. What about... }\end{array}$ & & & & \multirow{4}{*}{.61} & \multirow{4}{*}{.59} \\
\hline & Development of new products and services. & 3.73 & .829 & $.620^{\mathrm{a}}$ & & \\
\hline & $\begin{array}{l}\text { Customer/consumer (both internal and external) } \\
\text { satisfaction. }\end{array}$ & 3.63 & .749 & $.745^{* * *}$ & & \\
\hline & Relations among employees in general. & 3.75 & .816 & $.361^{* * *}$ & & \\
\hline \multirow{8}{*}{ HRM PRACTICES } & $\begin{array}{l}\text { Learning (on the job) and training are encouraged } \\
\text { in my organization. }\end{array}$ & 3.30 & 1.02 & $.798^{\mathrm{a}}$ & \multirow{8}{*}{.84} & \multirow{8}{*}{.84} \\
\hline & $\begin{array}{l}\text { Information on our organization's financial } \\
\text { results is provided to all employees. }\end{array}$ & 3.39 & 1.01 & $.526^{* * *}$ & & \\
\hline & Performance is evaluated by objective means. & 2.86 & .96 & $.631^{* * *}$ & & \\
\hline & $\begin{array}{l}\text { Individuals in my organization have opportunity } \\
\text { to develop and move to new tasks. }\end{array}$ & 2.97 & 1.06 & $.712^{* * *}$ & & \\
\hline & $\begin{array}{l}\text { Managers are aware of their subordinate's career } \\
\text { aspirations. }\end{array}$ & 3.13 & .97 & $.493^{* * *}$ & & \\
\hline & $\begin{array}{l}\text { Employees are encouraged to suggest } \\
\text { improvements in the way we work. }\end{array}$ & 3.23 & 1.01 & $.678^{* * *}$ & & \\
\hline & $\begin{array}{l}\text { We have flexible job and roles in my } \\
\text { organization. }\end{array}$ & 3.26 & .979 & $.559^{* * * *}$ & & \\
\hline & $\begin{array}{l}\text { In my organization jobs are deliberately allocated } \\
\text { to exploit the employees' skills and abilities as } \\
\text { effectively as possible. }\end{array}$ & 3.03 & .990 & $.648^{* * *}$ & & \\
\hline \multirow{7}{*}{$\begin{array}{c}\text { TRUST IN } \\
\text { ORGANIZATION }\end{array}$} & $\begin{array}{l}\text { There are work practices in my organization that } \\
\text { help us to overcome exceptional situations. }\end{array}$ & 3.35 & .890 & $.598^{\mathrm{a}}$ & \multirow{7}{*}{.78} & \multirow{7}{*}{.78} \\
\hline & $\begin{array}{l}\text { Employees have a bright future when working } \\
\text { with this employer. }\end{array}$ & 2.43 & 1.05 & $.617^{* * *}$ & & \\
\hline & $\begin{array}{l}\text { Our top management has a clear vision of the } \\
\text { future. }\end{array}$ & 3.17 & $\begin{array}{c}1.19 \\
8\end{array}$ & $.674^{* * *}$ & & \\
\hline & $\begin{array}{l}\text { I receive assistance with technical problems } \\
\text { whenever I need it. }\end{array}$ & 3.82 & .933 & $.554^{* * *}$ & & \\
\hline & $\begin{array}{l}\text { Outsiders consider my employer to be a } \\
\text { successful player in its field. }\end{array}$ & 3.52 & .941 & $.645^{* * *}$ & & \\
\hline & $\begin{array}{l}\text { The top management never puts their success } \\
\text { ahead of that of the employees. }\end{array}$ & 2.281 & .966 & $.521^{* * *}$ & & \\
\hline & $\begin{array}{l}\text { Top management has made it clear that unethical } \\
\text { action is not tolerated in my organization. }\end{array}$ & 3.526 & .950 & $.457^{* * *}$ & & \\
\hline
\end{tabular}

${ }^{a}$ Significance level is not available, because the coefficient is fixed at $1{ }^{* * *}$ Statistically significant at 0.01 significance level.

Measurement model for the individual performance model: Chi-square $=286.70, \mathrm{df}=147, \mathrm{P}=0.00$, RMSEA=0.048, GFI=0.931, NNFI=0.969, CFI=0.974, IFI=.974.

Measurement model for the unit-level performance model: Chi-square $=291.61, \mathrm{df}=165, \mathrm{P}=0.00$, RMSEA=0.043, GFI=0.934, NNFI=0.978, CFI=0.981, IFI=.981.

Measurement model for the organization-level performance model: Chi-square=279.53, $\mathrm{df}=147, \mathrm{P}=0.00$, RMSEA=0.047, GFI=0.933, NNFI=0.975, CFI=0.979, IFI=.979. 


\section{Appendix 2: Measurement items: study 2.}

\begin{tabular}{|c|c|c|c|c|c|c|}
\hline CONSTRUCT & ITEM & MEAN & SD & $\begin{array}{l}\text { FACTOR } \\
\text { LOADING }\end{array}$ & CR & $\alpha$ \\
\hline \multirow{3}{*}{$\begin{array}{r}\text { INDIVIDUAL } \\
\text { PEFORMANCE }\end{array}$} & I am satisfied with my work performance. & 3.87 & .928 & $.826^{\mathrm{a}}$ & \multirow{3}{*}{.74} & \multirow{3}{*}{.74} \\
\hline & $\begin{array}{l}\text { My employer is satisfied with my work } \\
\text { performance. }\end{array}$ & 4.02 & .806 & $.554^{* * *}$ & & \\
\hline & $\begin{array}{l}\text { I am satisfied with my work performance } \\
\text { compared to that of other employees who do the } \\
\text { same kind of job. }\end{array}$ & 4.00 & .925 & $.712^{* * *}$ & & \\
\hline \multirow{4}{*}{$\begin{array}{l}\text { UNIT-LEVEL } \\
\text { PERFORMANCE }\end{array}$} & $\begin{array}{l}\text { My unit has been successful in advancing and } \\
\text { supporting new business opportunities. }\end{array}$ & 3.51 & .985 & $.770^{\mathrm{a}}$ & \multirow{4}{*}{.78} & \multirow{4}{*}{.78} \\
\hline & $\begin{array}{l}\text { My unit has prepared well for future } \\
\text { opportunities and challenges. }\end{array}$ & 3.21 & 1.06 & $.843^{* * *}$ & & \\
\hline & $\begin{array}{l}\text { My unit has the relevant scientific, technical and } \\
\text { professional knowledge to cope with future } \\
\text { needs. }\end{array}$ & 3.81 & .936 & $.592^{* * *}$ & & \\
\hline & $\begin{array}{l}\text { My unit has adequate people and skills to convert } \\
\text { ideas into new products and services, and to } \\
\text { produce and implement them. }\end{array}$ & 3.46 & 1.03 & $.509^{* * *}$ & & \\
\hline \multirow{4}{*}{$\begin{array}{l}\text { ORGANIZATION- } \\
\text { LEVEL } \\
\text { PERFORMANCE }\end{array}$} & $\begin{array}{l}\text { How would you compare your organization's } \\
\text { performance over the past } 3 \text { years to that of other } \\
\text { successful organizations. What about... }\end{array}$ & & & & \multirow{4}{*}{.67} & \multirow{4}{*}{.65} \\
\hline & Development of new products and services. & 3.44 & .921 & $.793^{\mathrm{a}}$ & & \\
\hline & $\begin{array}{l}\text { Customer/consumer (both internal and external) } \\
\text { satisfaction. }\end{array}$ & 3.38 & .783 & $.660^{* * *}$ & & \\
\hline & Relations among employees in general. & 3.99 & .745 & $.418^{* * *}$ & & \\
\hline \multirow{8}{*}{ HRM PRACTICES } & $\begin{array}{l}\text { Learning (on the job) and training are encouraged } \\
\text { in my organization. }\end{array}$ & 3.77 & .969 & $.673^{\mathrm{a}}$ & \multirow{8}{*}{.81} & \multirow{8}{*}{.81} \\
\hline & $\begin{array}{l}\text { Information on our organization's financial } \\
\text { results is provided to all employees. }\end{array}$ & 3.62 & 1.11 & $.350^{* * *}$ & & \\
\hline & Performance is evaluated by objective means. & 3.29 & .985 & $.579^{* * *}$ & & \\
\hline & $\begin{array}{l}\text { Individuals in my organization have opportunity } \\
\text { to develop and move to new tasks. }\end{array}$ & 3.26 & 1.08 & $.743^{* * *}$ & & \\
\hline & $\begin{array}{l}\text { Managers are aware of their subordinate's career } \\
\text { aspirations. }\end{array}$ & 3.19 & .962 & $.624^{* * *}$ & & \\
\hline & $\begin{array}{l}\text { Employees are encouraged to } \\
\text { improvements in the way we work. }\end{array}$ & 3.42 & 1.13 & $.686^{* * * *}$ & & \\
\hline & $\begin{array}{l}\text { We have flexible job and roles in my } \\
\text { organization. }\end{array}$ & 3.44 & 1.01 & $.481^{* * *}$ & & \\
\hline & $\begin{array}{l}\text { In my organization jobs are deliberately allocated } \\
\text { to exploit the employees' skills and abilities as } \\
\text { effectively as possible. }\end{array}$ & 3.05 & .921 & $.548^{* * *}$ & & \\
\hline \multirow{7}{*}{$\begin{array}{c}\text { TRUST IN } \\
\text { ORGANIZATION }\end{array}$} & $\begin{array}{l}\text { There are work practices in my organization that } \\
\text { help us to overcome exceptional situations. }\end{array}$ & 3.11 & 1.01 & $.600^{\mathrm{a}}$ & \multirow{7}{*}{.76} & \multirow{7}{*}{.76} \\
\hline & $\begin{array}{l}\text { Employees have a bright future when working } \\
\text { with this employer. }\end{array}$ & 2.97 & .988 & $.725^{* * *}$ & & \\
\hline & $\begin{array}{l}\text { Our top management has a clear vision of the } \\
\text { future. }\end{array}$ & 3.19 & 1.07 & $.693^{* * *}$ & & \\
\hline & $\begin{array}{l}\text { I receive assistance with technical problems } \\
\text { whenever I need it. }\end{array}$ & 3.67 & .956 & $.440^{* * *}$ & & \\
\hline & $\begin{array}{l}\text { Outsiders consider my employer to be a } \\
\text { successful player in its field. }\end{array}$ & 4.02 & .794 & $.476^{* * *}$ & & \\
\hline & $\begin{array}{l}\text { The top management never puts their success } \\
\text { ahead of that of the employees. }\end{array}$ & 2.53 & .995 & $.537^{* * *}$ & & \\
\hline & $\begin{array}{l}\text { Top management has made it clear that unethical } \\
\text { action is not tolerated in my organization. }\end{array}$ & 3.68 & 1.11 & $.423^{* * *}$ & & \\
\hline
\end{tabular}

${ }^{a}$ Significance level is not available, because the coefficient is fixed at $1 .{ }^{* * *}$ Statistically significant at 0.01 significance level.

Measurement model for the individual performance model: Chi-square $=275.61, \mathrm{df}=147, \mathrm{P}=0.00$, RMSEA $=0.054, \mathrm{GFI}=0.913, \mathrm{NNFI}=0.956, \mathrm{CFI}=0.962, \mathrm{IFI}=.962$.

Measurement model for the unit-level performance model: Chi-square $=323.06, \mathrm{df}=165, \mathrm{P}=0.00$, RMSEA $=0.056, \mathrm{GFI}=0.904, \mathrm{NNFI}=0.960, \mathrm{CFI}=0.965, \mathrm{IFI}=.966$.

Measurement model for the organization-level performance model: Chi-square=270.43, $\mathrm{df}=147, \mathrm{P}=0.00$, RMSEA $=0.053, \mathrm{GFI}=0.914, \mathrm{NNFI}=0.961, \mathrm{CFI}=0.966, \mathrm{IFI}=.967$. 
Figure 1: Results for Study 1.

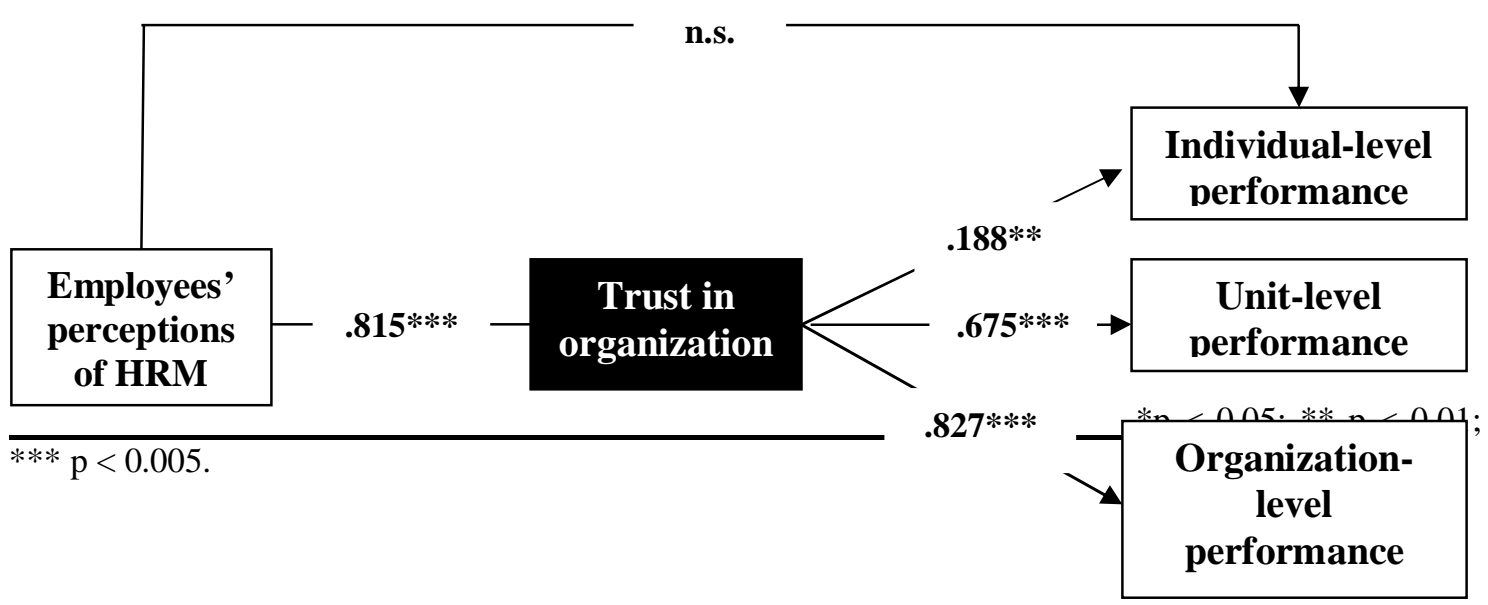

Figure 2 Results for Study 2.

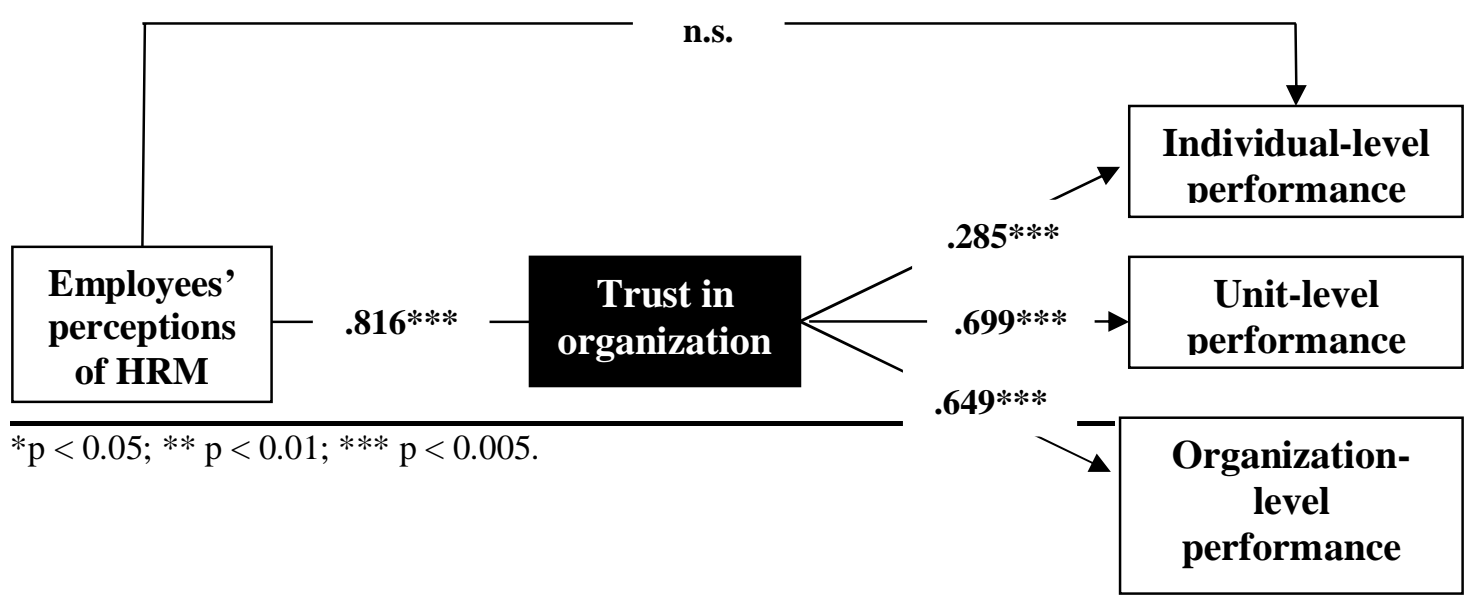


Figure 1: Results for Study 1.

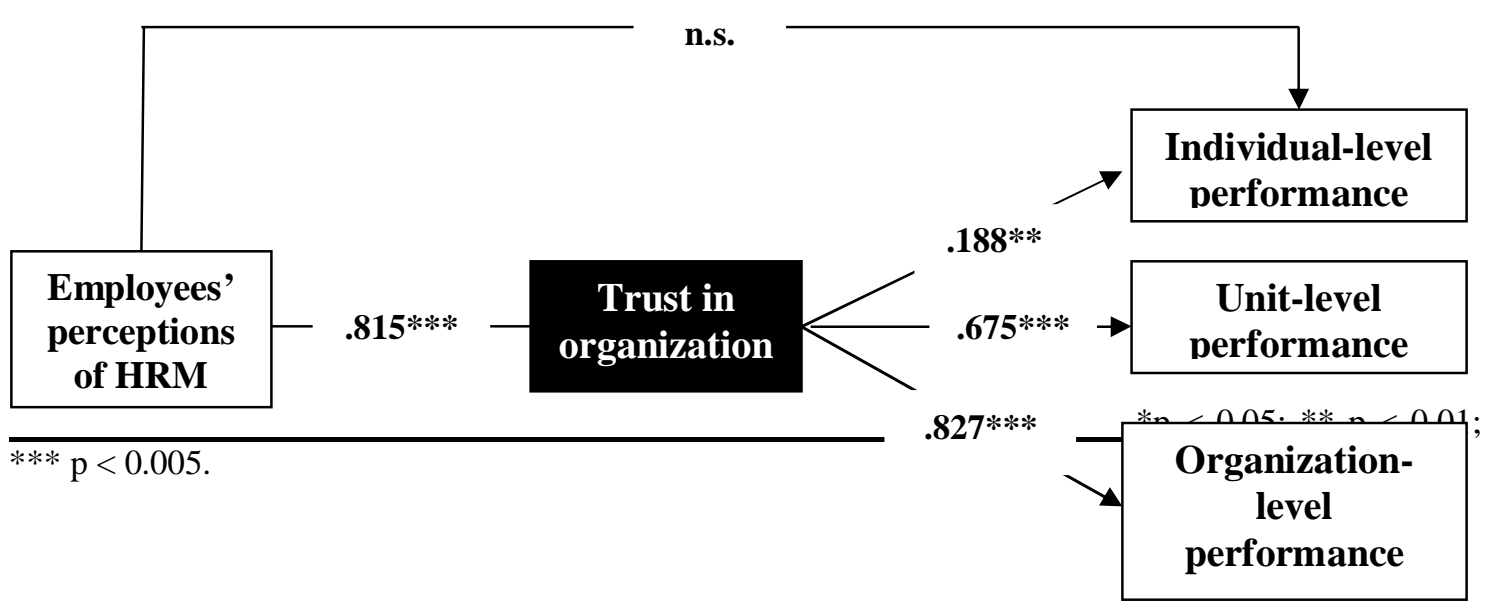

\section{Figure 2 Results for Study 2.}

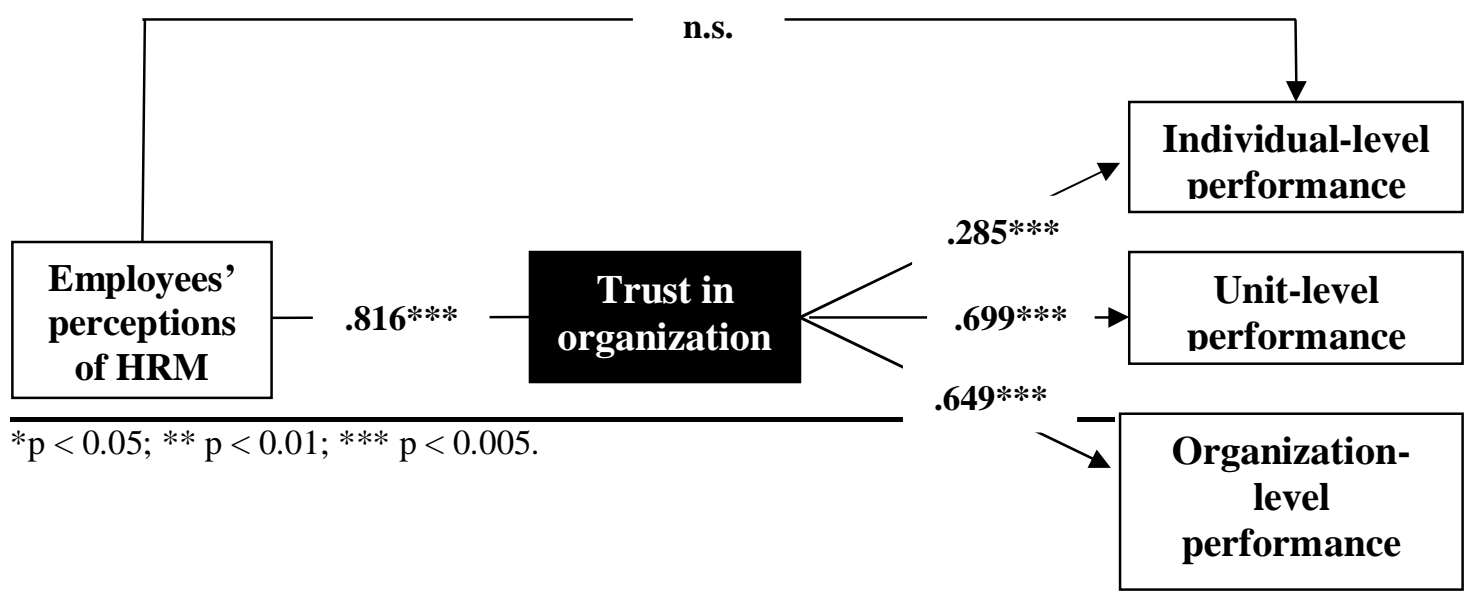

